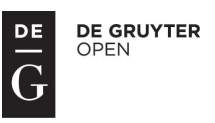

\title{
LABOUR TAXATION AND ITS IMPACT ON ECONOMIC GROWTH - COMPLEX ANALYSIS
}

\section{Rudolf Macek $^{1}$}

\begin{abstract}
The aim of the article is to provide a complex analysis of labour taxation impact on economic growth in OECD countries. As main approximators of taxation, implicit tax rates and the World Tax Index are used. Methods and tests of dynamic panel regression with the Arellano-Bond estimator are used from the methodological point of view. From the results of complex analysis, it is evident that there exists a non-linear relationship between tax revenues (implicit tax rates, world tax index) and tax burden (tax rates). There also exists a negative relationship between labour taxation and economic growth and the impact of labour taxation is the most harmful for economic growth. Therefore, in an effort to stimulate economic growth, labour taxation expressed by personal income taxes and social security contributions should be reduced.
\end{abstract}

\section{Keywords}

Labour Taxation, Implicit Tax Rates, World Tax Index, Laffer Curve, Economic Growth, Dynamic Panel Regression

\section{Introduction}

The last financial crisis in almost all developed countries has emphasized the debate about the impact of fiscal variables on economic growth not only among politicians, but also among economists and the public. In an effort to stabilize public budgets, economic policy authorities had to reduce government spending on the one hand and increase tax revenues on the other.

It is necessary to realize that the existence of redistributive processes is a necessity in our current globalized society due to the fulfilment of elementary state functions. The existence of taxes (main source of public budget revenues) and government spending (main expenditures of public budgets) can be therefore considered justified.

On the other hand, individual tax systems are very heterogeneous and include a lot of individual characteristics, e.g. tax rates, tax exemption, administrative costs of tax

\footnotetext{
${ }^{1}$ University of Social and Administrative Affairs, Vítězslava Nezvala 801/1, 73601 Havírov, Czech Republic.
} E-mail:macek@vsss.cz. 
payments and so on. Also, from the analysis of Johansson et al. (2008), it is evident that income taxes are the most harmful for economic growth. Personal income taxes and social security contributions are also part of income taxes and together they represent labour taxation. Labour taxation is one of the most important factors determining not only the labour market, but also capital accumulation, welfare and the standard of living of working people (Kaplow, 2008). There exists great potential for this type of taxation to determine the economic growth rate and therefore it is necessary to evaluate and quantify its impact in the complex analysis which is carried out in this article.

The aim of the article is to provide a complex analysis of the labour taxation impact on economic growth in OECD countries. As main approximators of taxation, implicit tax rates and the World Tax Index are used. The analysis is based on a modified neoclassical growth model of Mankiw, Romer and Weil (1992) and on methods and tests of dynamic panel regression with the Arellano-Bond estimator.

\section{Literature review - taxation and economic growth}

Taxation, or tax burden, represents one of the most significant factors that can influence economic growth and also social welfare, which can be considered to be the primary aim of economy policy makers. When we want to evaluate the impact of taxation on economic growth, it is evident that taxation can be integrated into growth theories only through its impact on individual growth variables (Macek, 2014a or Kotlán, Machová, Macek, 2015). Growth theories with regard to taxation must be understood as complex theories. Therefore, it is possible to say that labour taxation is only part of this complex theory. Barro and Sala-i-Martin (2004) state that the basic growth model can be derived from the Cobb-Douglas production function:

$$
Y=C+\dot{K}+\delta K=A(v K)^{\alpha}(w H)^{1-\alpha} .
$$

The individual accumulation of physical capital in economy $\dot{K}$ is possible to express as:

$$
\dot{K}=A(v K)^{\alpha}(w H)^{1-\alpha}-\delta K-C
$$

In both these expressions (1) and (2) $Y$ represents the total production; $C$ presents the private consumption; $\delta$ is the depreciation rate; $v$ expressed the part of the physical capital $(K)$ which is dedicated to the production; $w$ expressed the part of the human capital $(H)$ which is dedicated to the production; $A$ is the technological level and finally the coefficient $\alpha$ is the rate of diminishing returns to the physical capital.

Furthermore, by gradual derivation and adjustment, it will be possible to acquire the expression (3) from which it is evident that there are individually implemented taxes which are generally used in developed countries. Concretely, those are the labour taxes $\tau_{w}$, property taxes $\tau_{a}$, corporate taxes $\tau_{\pi}$ and consumption taxes $\tau_{c}$ (Kotlán, Machová, Macek, 2014). 


$$
\begin{aligned}
\gamma & =\frac{\stackrel{\circ}{\hat{k}}}{\hat{k}}=\left(1-\tau_{w}\right)\left[\frac{f(\hat{k})}{\hat{k}}-f^{\prime}(\hat{k})\right]+\left(1-\tau_{a}\right)\left[f^{\prime}(\hat{k})\left(1-\tau_{\pi}\right)-\delta\right]- \\
& -\left(1+\tau_{c}\right) \frac{\hat{c}}{\hat{k}}+\frac{\hat{t} r}{\hat{k}}-x-\frac{l}{l}
\end{aligned}
$$

Taxation influences economic growth through its impact on individual growth variables which are physical accumulation and human capital accumulation. King and Rebelo (1990) state that different tax policy of economic policy authorities can lead to significant disparity in economic growth between individual countries (see also Jovanović and Klun, 2017, on this topic).

According to Buettner and Ruf (2005), corporate taxation represents a significant factor which determines the foreign direct investment inflow. Pfaffermayr, Stockl and Winner (2008) state that corporate taxation lowers the return of invested capital and also affects the structure of capital or a company's age. In the context of globalization and significant mobility of factors, Adina (2009) evaluated the impact of tax policy on entrepreneurs and their localization decisions. The results of the analysis show that taxation plays an important role in an investor's decision. Statutory tax rates from capital can be considered a basic option of capital inflow and therefore countries with lower statutory tax rates from capital are clean foreign direct investments receivers (Lanaspa, Pueyo and Sanz, 2008). However, Becker and Fuest (2007) warn that the investor must also take into account other investment aspects, e.g. infrastructure, workforce availability, and legislation, etc.

Another view on investment activity insensitivity of economic subject is through dividend taxation (Lindop and Holland, 2013). The traditional approach finds a marginal source of investment in new own capital, where profits from investments are used to pay dividends. The new approach sees retained earnings as the source of investment. It can be deduced from the first approach that dividend taxation has an influence on investment activity, while the second view has an opposite opinion on this issue (e.g. Poterba and Summers, 1985). Currently, it is also necessary to work with the effect of capital and dividend taxation on small business transfers and start-ups. For more details see, e.g. Myeonghwam (2014).

Labour taxation affects economic growth through two channels. The first is visible in a reduction of entrepreneurial activities (Feld and Kirchgässner, 2001), the second lies in a savings decline (Leibfritz, Thornton and Bibbee,1997). Alesina et al. (1999) state that an increase in labour taxation (personal income tax or social security contributions) can lead to efforts on the part employees to increase their salary before taxation. This fact causes a net profit decline and therefore also a decline in net investments. According to Overesch and Voeller (2010), high labour taxation can also discourage companies from investment realization and determines the structure of capital accumulation (see also Uhrová and Skalka, 2016, on this topic). In the case of savings production, it is necessary to motivate economic subjects to increase the level of savings, but these tax stimuluses have to increase the savings level in a higher measure than these stimuluses reduce the tax revenues of public budgets (Engen, Gale and Scholz, 1994). Anyway, the partial positive 
effect of labour taxation can mean an increase of working effort with the aim to achieve the level of income before the taxation (Lubian and Zarri, 2011).

For completeness, the capital accumulation can be also influenced by consumption taxes, which have the same impact on investment as labour taxation (Salanié, 2003).

It is also necessary to realize that, in the case of the widened neo-classical growth model, taxation can influence the human capital. The positive relationship between the investment into human capital and long-term economic growth was confirmed in a lot of studies, see, e.g. Teixeira and Fortuna (2003). The positive dependency between taxation and economic growth exclusively exists if the tax revenues are used only for the human capital accumulation (Lin, 2001). On the other hand, it is important to say that human capital is characterised by its illiquidity and is highly risky (Grochulski and Piskorski, 2007). Especially due to these reasons, the financial institutions provide funds for investment into human capital at only a small rate. The most important motivational element for an employer to realize investment into human capital is tax relief.

\section{Complex empirical analysis: methodology, data and results}

The aim of the article is to provide a complex analysis of labour taxation impact on economic growth in OECD countries. In accordance with Barro and Sala-i Martin (2004), the homogenous group of countries will be analysed. These can be countries which have, e.g. similar production functions, institutional parameters, etc. This approach is fulfilled in this analysis, where the basic criterion for homogeneity is the country's membership in the OECD. It is evident that the OECD can be understood as a divergent group of countries. However, in the case of European Union countries, the problem can be caused by a limited number of observations and also the fact that the tax systems are harmonized and coordinated to some extent. It is necessary to realize that another, more homogenous, grouping of countries is not available. Also, Barro and Sala-i-Martin (2004) state that groups of countries where the growth theory is valid (so-called conditional convergence), exist within the growth theory; the OECD countries can be considered such a group of countries.

The analysis is based on a dynamic panel regression model, where the cross section is represented by individual countries of the OECD and the time aspect is the period 2000-2012 2 . The resulting number of observation is therefore equal to the product of number of analysed periods and number of cross-sectional units. The dynamic panel is characterised by the endogeneity existence, which is caused by the lagged value of the dependent variable. This endogeneity means that the lagged value of the dependent variable can be correlated with independent variables and residuals. Therefore, the model cannot be estimated with the OLS (ordinary least squared) method, but a special differenced form of GMM (generalized method of moment) with instrumental variables (standard IV estimator, resp. Arellano-Bond estimator) has to be used (Arellano a Bond, 1991). The

${ }^{2}$ Data for the WTI, see below, is not available in a sufficiently consistent and reliable form for a longer period of time in view of changes in the calculation methodology, see Machová and Kotlán (2013). 
possible existence of autocorrelation and heteroskedasticity was eliminated with the White period method. The main econometric program was E-views, version (8).

In our article, taxation is expressed by implicit tax rates and the World Tax Index. Therefore, now is the time to introduce them. Implicit tax rates represent an appropriate measure for effective tax burden comparison. These tax rates do not relate their tax collection to the GDP as a base, but to the activity which is directly affected by the tax. Therefore, it is possible to express the real tax burden of labour (ITRL), capital (ITRC) and consumption (ITRc). Furthermore, this approximator does not take into account only the level of statutory rates, but also other aspects of tax systems, e.g. tax benefits, tax reliefs or tax surcharges. Vogel (2009) states that, if tax deductible items exist, then no statutory tax rate will be at the same level as the implicit tax rate. These rates are calculated according to harmonized systems of national and regional accounts - ESA95 (Bach, 2009).

The World Tax Index represents an alternative approximator of taxation which combines hard data (OECD, World Bank) and soft data (broad questionnaire exploration) and expresses the real tax burden. It is an aggregate multicriteria indicator of the tax burden, which is based on the combination of information about tax conditions available at internationally respected sources (World Bank - Doing Business) with information expressing expert opinions (Qualified Expert Opinion - QEO). The tax burden is expressed by a relative way in relation to other researched countries, where the higher value of the World Tax Index will represent a higher tax burden. The tax burden is expressed in a relative way in relation to other researched countries, where the higher value of the World Tax Index will represent a higher tax burden. This approximator also tries to implement into the tax burden the evaluation of other important aspects connected with real tax burden, e.g. tax rates, tax exemption, administrative costs of tax payments, deductibles, tax progressivity, etc. The World Tax Index represents a multicriterial index which consists of multiple sub-indexes, specifically - CIT (Corporate Income Tax), PIT (Personal Income Tax, Social Security Contributions), VAT (Value Added Tax), OTC (Other Taxes on Consumption) and PRO (Property Taxes). For more information about construction and methodology, see Kotlán and Machová (2012).

The data about the GDP amount per capita in purchasing power parity and government spending were drawn from OECD database National Accounts Statistics. ${ }^{3}$ The information about the amount of ratio of investments on GDP is acquired from the Penn World Table (Penn World Table - database 1950-2012). ${ }^{4}$ Information about human capital was acquired from the new database of the Penn World Table (Feenstra, Inklaar and Timmer, 2013). Data about implicit tax rates are from the database of Eurostat $(2018)^{5}$ and the World Tax Index is from Kotlán and Machová (2012).

\footnotetext{
${ }^{3}$ OECD National Accounts Statistics - available from https://www.oecd-ilibrary.org/economics/data/nationalaccounts-at-a-glance_naag-data-en.

${ }^{4}$ Penn World Table - available from https://pwt.sas.upenn.edu/php_site/pwt_index.php.

${ }^{5}$ Eurostat Statistics - available from http://epp.eurostat.ec.europa.eu/portal/page/portal/statistics/search_database.
} 
Econometric analysis is based on the model of Mankiw, Romer and Weil (1992). This modified model is one of the most used ones, because it widens the basic neoclassical growth model by human capital. According to this model, it is possible to write individual variables which model:

$\diamond$ GDP - gross domestic product growth per resident expressed by the amount of real GDP per capita in purchasing power parity in USD (dependent variable) [USD/resident];

$\diamond \mathrm{CAP}$ - capital accumulation approximated by indicator of proportion of real investments to GDP, expressed in purchasing power parity per one resident [\%];

$\diamond \mathrm{HC}$ - human capital expressed with the index of human capital per one resident based on the number of schooling years and return on investment in education;

$\diamond \mathrm{GOV}$ - total government spending as a \% GDP [\%];

$\diamond \mathrm{TAX}$ - taxation rate approximated by tax implicit tax rates (ITR) [\%] and World Tax Index (WTI).

From the original model, the variable "Population" is removed because this variable was not statistically significant it is in harmony with current author's works - see e.g. Macek (2014b) or Macek (2015).

According to the above statement and in regard with the dynamic panel regression, it is possible to write the explored mathematical formula shown in equation (4):

$$
\begin{aligned}
H D P_{i t} & =\gamma H D P_{i, t-1}+\hat{\beta} C A P_{i t}+\hat{\beta} H C_{i t}+\hat{\beta} G O V_{i t}-\hat{\beta} T A X_{i t}+\alpha_{i}+u_{i t} . \\
i & =1 \ldots 34 ; t=2000 \ldots 2012
\end{aligned}
$$

At first, the individual variables entering into the analysis were transformed into logarithms. Due to that, it is possible to interpret the resulting coefficients, if some independent variable changes by $1 \%$ this fact will lead to the growth or decrease of the GDP growth rate by the amount of the estimated coefficient.

Then the stationarity of the time series was tested, where the hypothesis of the existence of a single root is tested. The time series stationarity of individual variables was explored by the tests of Levin, Lin and Chu (2002); Im, Pesaran and Shin (2003) and ADF and $\mathrm{PP}$ tests according to Maddalu and $\mathrm{Wu}$ (1999). The existence of unit root was confirmed in the case of gross domestic product, human capital, government spending, implicit tax rates of labour and sub-index VAT. Their stochastic instability was removed by using first differences which have already shown the stationarity.

With regard to the analysed issue, it is necessary to realize that all variables should have the same base and form. Therefore, the first differences were used in case of all variables so they entered into the model as a first difference of logarithmic value.

Before the results of the analysis are shown, it is appropriate to explore the potential connection between tax revenues expressed by implicit tax rates on labour, eventual Personal Income Tax and the size of the tax burden expressed by tax rate. In considering the representative type of tax rate, it has to be taken into account that the tax rate differs in the case of a married couple or single persons and also in the case of children in the 
family, etc. Therefore, the tax rate related to a single childless person was chosen as the representative tax rate. The correlation between the chosen variables was made for the year 2012 for all OECD countries. In identifying and evaluating this potential connection, numerous models were estimated where individual values were gradually transferred into line and parabola. Table 1 shows the values of achieved coefficients of determination in individual cases. It is obvious that the coefficients of determination are low, but from the view of statistical verification the use of parabola is more appropriate.

Table 1: Characteristics of Laffer curve in case of ITRL and PIT

\begin{tabular}{|l|c|c|}
\hline & ITRL & PIT \\
\hline Function Linear & 0,226 & 0,316 \\
\hline Function Quadratic & 0,264 & 0,355 \\
\hline
\end{tabular}

Source: own calculations

Figure 1: Laffer curve for ITRL and PIT
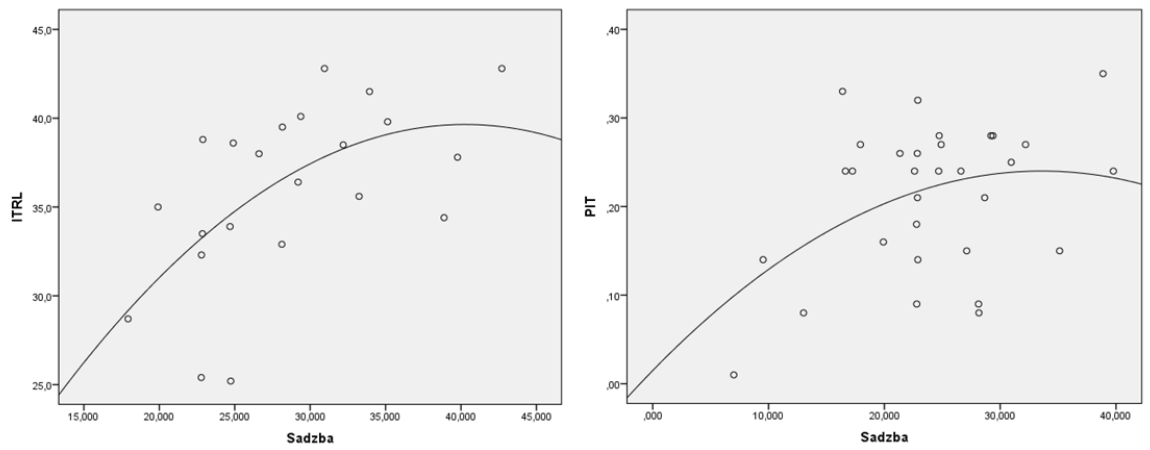

Source: own calculations

Figure 1 graphically illustrates the Laffer curve for the implicit tax rate on labour (left-hand side) and Personal Income Tax (right-hand side). In both cases it is obvious that, between the tax burden (tax rate) and tax revenues (implicit tax rates on labour, Personal Income Tax) there exists a non-linear relationship. This means that, in the case of a low tax burden, a positive correlation to the implicit tax rates and Personal Income Tax exists and from a higher tax burden - about 40\% (ITRL) and about 32\% (PIT), the relationship is negative.

Table 2: The impact of labour taxation on economic growth in OECD (2000-2012)

\begin{tabular}{|l|c|}
\hline Dependent variable & D(LOG(HDP)) \\
\hline Number of observations & 131 \\
\hline Number of instruments & 13 \\
\hline J-statistics & 7,860 \\
\hline Probability J-statistics & 0,249 \\
\hline
\end{tabular}




\begin{tabular}{|l|c|c|}
\hline & coefficient & t-statistics \\
\hline $\mathrm{D}($ LOG $($ HDP $(-1)))$ & 0,634 & $5,519 * * *$ \\
\hline $\mathrm{D}(\mathrm{LOG}(\mathrm{CAP}))$ & 0,335 & $32,801 * * *$ \\
\hline $\mathrm{D}(\mathrm{LOG}(\mathrm{HUM}))$ & 0,109 & 0,147 \\
\hline $\mathrm{D}(\mathrm{LOG}(\mathrm{GOV}(-1)))$ & 0,208 & $2,573 * * *$ \\
\hline $\mathrm{D}(\mathrm{LOG}(\operatorname{ITRC}(-2)))$ & $-0,025$ & $-3,301 * * *$ \\
\hline $\mathrm{D}(\mathrm{LOG}(\operatorname{ITRL}(-1)))$ & $-0,191$ & $-2,799 * * *$ \\
\hline $\mathrm{D}($ LOG $(\operatorname{ITRc}(-2)))$ & $-0,030$ & $-0,809$ \\
\hline
\end{tabular}

\begin{tabular}{|l|c|c|}
\hline Dependent variable & \multicolumn{2}{|c|}{ D(LOG(HDP)) } \\
\hline Number of observations & \multicolumn{2}{|c|}{244} \\
\hline Number of instrument & \multicolumn{2}{|c|}{33} \\
\hline J-statistics & \multicolumn{2}{|c|}{22,880} \\
\hline Probability J-statistics & \multicolumn{2}{|c|}{0,242} \\
\hline & coefficient & t-statistics \\
\hline D(LOG(HDP(-1))) & 0,502 & $3,399 * * *$ \\
\hline LOG(CAP) & 0,272 & $11,273^{* * *}$ \\
\hline LOG(HUM) & 1,660 & $2,873 * * *$ \\
\hline D(LOG(GOV(-1))) & 0,342 & $2,791 * * *$ \\
\hline D(LOG(CIT(-1))) & $-0,082$ & $-2,629 * * *$ \\
\hline LOG(PIT(-2)) & $-0,170$ & $-1,629 *$ \\
\hline LOG(VAT(-1)) & $-0,016$ & $-0,286$ \\
\hline LOG(OTC(-2)) & $-0,064$ & $-5,739 * * *$ \\
\hline D(LOG(PRO(-1)) & 0,045 & 0,835 \\
\hline
\end{tabular}

Note: $*, * *, * * *$ represent the significance level at $10 \%, 5 \%$ and $1 \%$.

Source: own computation

From Table 2, it is obvious that within the model is a whole two essential conditions for the dynamics panel are fulfilled. The number of instruments is larger than J-statistics and the probability of J-statistics (Sargan test) is at the level $24.9 \%$ (implicit tax rates) or ultimately $24.2 \%$ (World Tax Index), which means that instruments are chosen properly. It is possible to say with high probability that endogeneity was removed from the model. It is also visible that the lagged value of the dependent variable is significant at a $1 \%$ significance level in both models, which means that the use of dynamic panel regression is justified.

Capital accumulation is also statistically significant at a $1 \%$ significance level in both models and the positive relationship was confirmed with economic growth. This fact can be connected with the conclusions of the basic neoclassical growth model. In this model, the growth of capital accumulation (represented by increased savings or investment activity) is the basic source of economic growth up to the achievement of a stable state. Based on 
this and due to its statistical significance, it is possible to assume that OECD countries have not yet reached a stable state.

In the first analysed model, human capital is not statistically significant, but this variable was kept in the model as a basic growth "controlled" variable. In the second model, human capital is statistically significant at a $1 \%$ significance level. In both cases this variable is positively linked with economic growth and therefore it is evident that human capital, resp. investments into human capital raise economic growth and can be considered a source of long-run economic growth.

Now it is possible to focus on fiscal variables (government spending and taxes). It is necessary to realize that the econometric significance of the fiscal variables time lag is justified, because the change of government spending (taxes) level or structure is one of the basic economic policy-maker's decisions. This decision is accompanied by a certain time lag. In the case of government spending (statistically significant at a $1 \%$ significance level), the positive theoretical assumption was proven, which means that the positive effect of the positive part of government spending prevails, see, e.g. Kneller, Bleaney and Gemmell (1999) or Kotlán and Macek (2014).

Corporate taxation is statistically significant at a $1 \%$ significance level, with a negative relationship with economic growth. It is obvious that this type of taxation reduces the return of capital, FDI inflow and capital accumulation. To see which factors can influence corporate tax revenues, see, e.g. Macek (2014c).

For the purposes of this article, labour taxation is perceived by personal income taxes and social security contributions. Both of these are included in the implicit tax rates on labour or Personal Income Tax. From the results of the analysis, it is obvious that implicit tax rates on labour are statistically significant at a $1 \%$ significance level and Personal Income Tax at a $10 \%$ significance level. It is also visible that the impact of this type of taxation on economic growth is negative and the most harmful for economic growth. The hypothesis was proven that this type of taxation has the strongest impact on economic growth through its connectedness with the labour market and impact on savings creation.

These two channels will be now described:

$\diamond$ labour taxation reduces the economic growth and then gradually also welfare and the standard of living of working individuals. It is necessary to realize that this type of tax reduces the creation of savings as the basic source of investments in the neoclassical growth model. There is also subsequently a decrease of disposable sources which finance investments and therefore the number of realized investments also falls;

$\diamond$ the second channel is visible through the connectedness of labour taxation with the labour market. Growth of labour taxation causes a decrease in the labour supply, which can be problematic in the case of a highly specialised work force. The increase of labour taxation also causes a rise in labour costs, which creates pressure to lower enterprise profits. Due to this, enterprises abandon investment localization and the structure of capital accumulation also changes. In addition, the increase in labour costs causes the substitution of labour by capital and decreases 
the marginal product of capital. Therefore, from a long-term view, this leads to growth in unemployment, which is also connected with a low rate of product growth.

The impact of consumption taxes is negative, but in the case of implicit tax rates on consumption, Value Added Tax is not ultimately statistically significant.

Property taxes are positively linked with economic growth. In this case, it is possible to identify with the results of Tosun and Abizadeh (2005), who state that the increasing share of property taxes has a positive impact on economic growth. Property taxes have the smallest share in the total tax mix of OECD countries (expressed by tax quota), but their share has gradually increased over the period. For this reason, the positive relationship between property taxes and economic growth can be considered justified.

\section{Conclusion}

The aim of the article was to provide a complex analysis of labour taxation impact on economic growth in OECD countries. From the methodological point of view, methods and tests of dynamic panel regression with the Arellano-Bond estimator were used. Also, implicit tax rates and the alternative World Tax Index were used in complex analysis as the main approximators of taxation.

The first part of the analysis was to explore the potential connection between tax revenues (implicit tax rates on labour and Personal Income tax) and the size of the tax burden expressed by the tax rate. These relationships were non-linear, which means that there exists a Laffer curve between these variables. In the case of implicit tax rates on labour, there exists a Laffer point at the level of around $40 \%$ and in the case of Personal Income Tax, the Laffer point is at the level of around $32 \%$.

The second part consisted of a dynamic panel regression. The lagged value of the dependent variable (economic growth) was statistically significant, so the use of a dynamic panel was justified.

Capital accumulation has positive impact on economic growth and this variable was statistically significant in both analysed models. Therefore, it is possible to say that OECD countries have not yet reached a stable state. In the case of human capital, the positive theoretical assumption was proven, but this variable was statistically significant only in the case of the model with the World Tax Index. It is also possible to state that investments into human capital are a source of long-run economic growth.

Corporate taxation was statistically significant in both models and its impact on economic growth is negative. This type of taxation reduces the return of capital, foreign direct investments inflow and finally also capital accumulation.

Labour taxation was statistically significant in both analysed models. The hypothesis was also proven that this type of taxation can be the most harmful for economic growth. It is necessary to see this impact through the connectedness with the labour market and impact on savings creation. In this case, savings can be considered a main source of capital accumulation. 
The impact of consumption taxes is negative. The impact of property taxes on economic growth is positive and can be caused by increasing the share of property taxes in the total tax mix of OECD countries.

Based on the above, it is possible to say that labour taxation is the most harmful for economic growth and OECD countries in an effort to stimulate economic growth should reduce labour taxation and raise property taxes. Also, the final tax system should be a result of society-wide consensus.

\section{References}

Adina, M. (2009). The Impact of Taxation on the Investment Localization Decision in the Context of Globalization. Analele Stiintifice ale Universitatii Alexandru Ioan Cuza din Iasi, 56(1), 133-142.

Alesina, A. et al. (1999). Fiscal Policy, Profits and Investment. National Bureau of Economic Research, Working Paper No. 7207.

Arellano, O. and Bond, S. (1991). Some Tests of Specification for Panel Data: Monte Carlo Evidence and an Application to Employment Equations. The Review of Economic Studies, 58(2), 277-297.

Bach, S. (2009). The Impact of Loses on Income Tax Revenue and Implicit Tax Rates of Different Income Sources. DIW Wochenbericht, Working Paper No. 950.

Barro, R. and Sala-i-Martin, X. (2004). Economic Growth (2nd ed). London: The MIT Press.

Becker, J. and Fuest, C. (2007). Quality versus Quantity - the Composition Effect of Corporate Taxation on Foreign Direct Investment. CESifo, Working Paper No. 2126.

Buetner, T. and Ruf, M. (2005). Tax Incentives and the Location of FDI: Evidence from a Panel of German Multinationals. Deutsche Bundesbank, Working Paper No. 17.

Engen, E., Gale, W. and Scholz, J. (1994). Do Saving Incentives Work? Bookings Papers on Economic Activity, 25(1), 85-180.

Feenstra, R., Inklaar, R. and M. Timmer (2013). The Next Generation of the Penn World Table. National Bureau of Economic Research, Working Paper No. 19255.

Feld, L. and Kirchgässner, G. (2001). The Impact of Corporate and Personal Income Taxes on the Location of Firms and on Employment: Some Panel Evidence for Swiss Cantons. Center for Economic Studies, Working Paper No. 455.

Grochulski, B. and Piskorski, T. (2007). Risky Human Capital and Deferred Capital Income Taxation. Federal Reserve Bank of Richmond, Working Paper No. 06-13.

Im, K., Pesaran, H. and Shin, Y. (2003). Testing for Unit Roots in Heterogeneous Panels. Journal of Econometrics, 115(1), 53-74.

Johansson, A. et. al (2008). Tax and Economic Growth. OECD Economics Department, Working Paper No. 20, 2-82.

Jovanović, T., Klun, M. (2017). Tax Policy Assessment in Slovenia - Case of Interest Tax Shield. DANUBE: Law, Economics and Social Issues Review, 8(1), 1-17.

Kaplow, L. (2008). The Theory of Taxation and Public Economics. Princeton: Princeton University Press. 
King, R. and Rebelo, S. (1990). Public Policy and Economic Growth: Developing Neoclassical Implications. Journal of Political Economy, 98(5), 126-150.

Kneller, R., Bleaney, M. and Gemmell, N. (1999). Fiscal Policy and Growth: Evidence from OECD Countries. Journal of Public Economics, 74(2), 171-190.

Kotlán, I., Machová, Z. and Macek, R. (2015). "Not a Tax as a Tax: Tax Burden Indicators Revised", in: Soliman, K. (eds.). Proceedings of the 25th International Business Information Management Association Conference Innovation Vision 2020: From Regional Development Sustainability to Global Economic Growth. Norristown: IBIMA Publishing, 2015.

Kotlán, I., Machová, Z. and Macek, R. (2014). "Influence of Tax Uncertainty and Government Expenditures Volatility on Economic Growth - Case Study of OECD Countries", in: Vrontis, D., Weber, Y., Tsoukatos, E. (eds.). Proceedings of the 7th Annual EuroMed Conference of the EuroMed Academy of Business. Kristiansand: Euromed, 2014.

Kotlán, I. and Macek, R. (2014). "What is the Horizon of Fiscal Policy in OECD Countries?" in: Soliman, K. (eds.). Proceedings of the 23rd International Business Information Management Association Conference Innovation Vision 2020: Sustainable Growth, Economic Development and Global Competitiveness. Norristown: IBIMA Publishing, 2014. Kotlán, I., Machová, Z. (2012). World Tax Index: Methodology and Data. DANUBE: Law, Economics and Social Issues Review, 3(2), 18-33.

Lanaspa, L., Pueyo, F. and Sanz, F. (2008). Foreign Direct Investment, Industrial Location and Capital Taxation. The Annals of Regional Science, 42(2), 413-423.

Leibfritz, W., Thornton, J. and Bibbee, A. (1997). Taxation and Economic Performance. OECD Economics Department, Working Paper No. 176.

Levin, A., Lin, Ch. and Chu. Ch. (2002). Unit Root Tests in Panel Data: Asymptotic and Finite-Sample Properties. Journal of Econometrics, 108 (1), 1-24.

Lin, S. (2001). Taxation, Human Capital Accumulation and Economic Growth. Japanese Economic Review, 52(2), 185-197.

Lindop, S. and Holland, K. (2013). Dividend Taxation and the Pricing of UK Equities. Journal of Applied Accounting Research, 14(3), 203-223.

Lubian, D. and Zarri. L. (2011). Happiness and Tax Morale: An Empirical Analysis. University of Veroa, Working Paper No. 04.

Maddala, G. and Wu, S. (1999). A Comparative Study of Unit Root Tests with Panel Data and a New Simple Test. Oxford Bulletin of Economics and Statistics, 61(0), 631-652.

Mankiw, G., Romer, D. and D. Weil (1992). A Contribution to the Empirics of Economic Growth. The Quarterly Journal of Economics, 107(2), 407-437.

Macek, R. (2015). Vplyv jednotlivých typov daní na ekonomický rast v krajinách OECD: dynamická panelová regresia. Ekonomický časopis, 63(7), 718-736.

Macek, R. (2014a). "Labour Taxation and Its Impact on Economic Growth in the OECD Countries", in: Tvrdoň, M., Majerová, I. (eds.). International Scientific Conference on Economic Policy in the European Union Member Countries. Opava: Silesian University School of Business Administration, 2014.

Macek, R. (2014b). The Impact of Taxation on Economic Growth: Case Study of OECD Countries. Review of Economic Perspectives, 14(4), 309-328. 
Macek, R. (2014c). "Which Factors Influence the Corporate Tax Revenues in European Union Countries?”, in: Gaubova, G. (eds.) Taxes in the World: 4th International Scientific Conference. Vienna: EACO, 2014.

Machova, Z., Kotlan, I. 2013. World Tax Index: New Methodology for OECD Countries, 2000-2010. DANUBE: Law, Economics and Social Issues Review, 4(2), 165-179.

Myeonghan, Ch. (2014). The Effect of Capital Gains Taxation on Small Business Transfers and Start-ups. Economic Modelling, 36(1), 447-454.

Overesch, M. and Voeller, D. (2010). The Impact of Personal and Corporate Taxation on Capital Structure Choices. Financz Archiv, 66(3), 263-294.

Pfaffermayer, M., Stock1, M., and Winner, H. (2008). Capital Structure, Corporate Taxation and Firm Age. University of Innsbruck, Working Paper No. 2008-09.

Poterba, J. M. and Summers, L. H. (1985). The Economic Effects of Dividend Taxation. National Bureau of Economic Research, Working Paper No.1353.

Salanié, B. (2003). The Economics of Taxation. Cambridge: MIT Press.

Teixeira, A. and Fortuna, N. (2003). Human Capital, Innovation Capability and Economic Growth. Faculdade de Economia, Working Paper No. 131.

Tosun, M. and Abizadeh, S. (2005). Economic Growth and Tax Components: An Analysis of Tax Changes in OECD. Applied Economics, 37(19), 2251-2263.

Uhrová, N., Skalka, P. (2016). The Impact of Minimum Wage Changes on Management in the Czech Republic. DANUBE: Law, Economics and Social Issues Review, 7(3), 183-189. Vogel, L. (2009). Tax Avoidance and Fiscal Limits: Laffer Curves in an Economy with Informal Sector. European Commission, Working Paper. 